\title{
Identification of Phenotypic and Genotypic Variability among the Isolates of Ramularia areola of Brazilian Cotton
}

\author{
Larissa Girotto $^{1}$, Mariana S. Marangoni ${ }^{1}$, Janaina N. Matos ${ }^{1}$, Rafael Galbieri ${ }^{2}$, Wilson P. Almeida ${ }^{1}$, \\ Yeshwant R. Mehta ${ }^{1^{*}}$ \\ ${ }^{1}$ Instituto Agronômico do Paraná-IAPAR, Londrina, Brazil; ${ }^{2}$ Instituto Mato-Grossense do Algodão-IMA, Primavera do Leste, \\ Brazil. \\ Email: *yrmehta@iapar.br
}

Received July $1^{\text {st }}, 2013$; revised August $1^{\text {st }}, 2013$; accepted August $20^{\text {th }}, 2013$

Copyright (C) 2013 Larissa Girotto et al. This is an open access article distributed under the Creative Commons Attribution License, which permits unrestricted use, distribution, and reproduction in any medium, provided the original work is properly cited.

\begin{abstract}
Genotypic and phenotypic variation among 16 isolates of Ramularia areola of Gossypium hirsutum collected from five different geographical regions of Brazil was studied through virulence spectrum on three cultivars in the glasshouse and through ERIC- and REP-PCR and ITS1-5.8S-ITS2 rDNA analysis. Difference in virulence spectrum and molecular analysis of some isolates was observed. ERIC- and REP-PCR showed similar results and revealed a high level of diversity among the isolates. A unique profile for both ERIC and REP was obtained for most isolates. On the other hand, the ITS rDNA analysis did not show different PCR-RFLP patterns. While some isolates differed among each other considering genotypic and phenotypic reactions, no clear cut evidence was found about the existence of genetic lineages of $R$. areola in Brazil. Identification of genetic variability among the $R$. areola isolates originated from different geographic regions would permit screening of Brazilian germplasm and achieve sources with a wide spectrum of resistance. This is the first report of the genotypic and phenotypic variability among the $R$. areola isolates originated from five cotton growing regions of Brazil.
\end{abstract}

Keywords: Ramularia; False Mildew; Genotypic and Phenotypic Differentiation; Gossypium hirsutum

\section{Introduction}

Leaf blight of cotton caused by Ramularia areola is economically important especially for Brazil, causing heavy yield losses [1-4]. In Brazil, some years ago it was considered as a secondary and late season disease, however, in recent years the disease is of principal concern especially because now it attacks cotton during the entire crop cycle. In the Cerrado region of Brazil the yield losses caused by this disease are estimated to be around 30\% but in severe cases they can be up to $75 \%$ in the State of Mato Grosso [1,2,4]. Yield losses of over $60 \%$ are also recorded in Madagascar [5]. At present the disease is partially controlled in Brazil by $5-8$ applications of fungicides thereby adding to the cost of cultivation and at the same time making the intensive use of fungicides almost unsustainable in the course of time. Resistance of some genotypes was detected under field conditions but their resistance was not found to be consistent presumably because of the genetic variability among the patho-

"Corresponding author. gen population [1-4].

Although the perfect state of the pathogen is not known to occur in nature, existence of "field strains" is believed to be present in Brazil. So far, cultivars resistant to different "field strains" of $R$. areola are not yet available. It is obvious that the disease can be controlled through the use of resistant cultivars but for this it is necessary to identify the phenotypic and genotypic variability among the $R$. areola isolates.

Differential reaction of some cotton cultivars to four isolates of $R$. areola was studied in the United States as early as in 1976 [6]. Recently, variability among the 23 isolates of $R$. areola of Brazilian cotton originated from different geographical regions was studied by Pezenti et al. [3], using three Gossypium hirsutum genotypes under glasshouse conditions. These authors demonstrated that the three genotypes were useful in distinguishing phenotypic variability among some isolates. Genetic differentiation among the isolates of $R$. areola has not been reported so far either from Brazil or from elsewhere in the world. 
The objective of the present investigation was to verify phenotypic and genotypic variability among $16 \mathrm{R}$. areola isolates collected from different geographical regions of Brazil, through their virulence spectrum in the glasshouse and through ERIC- and REP-PCR and ITS1-5.8SITS2 rDNA. The objective was also to comprehend relationship between their phenotypic and genotypic variation.

\section{Material and Methods}

Fungal Isolates: Out of the 23 isolates of $R$. areola studied earlier for phenotypic variation [3], 16 isolates were used in this study for phenotypic and genotypic variation since other isolates had lost their pathogenicity due to constant culturing in artificial media. These isolates are considered representatives of the pathogen occurring across the cotton growing areas of Brazil and their origin is presented in Table 1. Fungal isolates were grown in Petri plates containing V8 juice agar for three weeks, the growth was scraped from the plates with distilled water and a few drops of Tween 20 was added to the suspension. Conidial concentration was adjusted to $10^{6}$ conidia $\mathrm{ml}^{-1}$. Twenty five days old plants of three cotton genotypes (FMT 701, FMT 02102996, CNPA BA 2003-2059) grown in the glasshouse were inoculated individually. Twelve plants of each cultivar were inoculated by a hand sprayer till run off and were incubated in dark for $24 \mathrm{~h}$ at approximately $80 \%$ humidity, and later were transferred to the glass-house bench [3].

Disease Rating: Leaf of each plant showing the highest level of infection was scored 30 days after inoculation using a visual scale of $0-3$, where $0=$ No symptoms of the disease; $1=$ Small pin point necrotic spots without chlorosis, covering $<1 \%$ leaf area infected, and incapable of producing sporulation in a humid chamber under the laboratory conditions; 2 = Symptoms typically angular with chlorosis measuring $2-3 \mathrm{~mm}$, covering $>1 \%$ leaf area infected, with or without apparent sporulation; $3=$ Symptoms typically angular, coalescing, covering $>25 \%$ leaf area infected, with or without apparent sporulation, with severe chlorosis and causing premature death of the leaves. For the purpose of identification of phenotypical differences, disease ratings between 0 and 1 were considered Resistant (Incompatible reaction), and ratings between 2 and 3 were considered Susceptible (Compatible reaction).

DNA Extraction: Fungal cultures were grown in Petri plates containing $15 \mathrm{~mL}$ of V8-juice agar for three weeks, the fungal growth was scraped from the plates and the total DNA was extracted as described by Raeder \& Broda [7]. DNA was quantified by a DyNa Quant 200 Fluorometer (Pharmacia) and RNA was eliminated by RNase $\left(10 \mu \mathrm{g} \cdot \mathrm{mL}^{-1}\right)$.
ERIC- and REP-PCR: We used Enterobacterial Repetitive Intergenetic Consensus (ERIC) and Repetitive Extragenic Palindromic Sequence (REP) PCR fingerprinting, and the analysis of internal transcribed spacer of rDNA to identify genetic variability of $R$. areola. Use of the ERIC/REP-PCR was originally reported for genomic fingerprints of phytopathogenic bacteria [8]. In the recent years, ERIC/REP-PCR is also being used do detect genetic variability among fungal pathogens of several crops $[9,10]$. The sequences of the primers are ERIC1R5'-ATGTAAGCTCCTGGGGTTCAC-3'; ERIC2-5'AAGTAAGTGACTGGGGTGAGCG-3'; REP1R-1-5' IIICGICGICATCIGGC-3'; REP2-1-5'-ICGICTTATCIGGCCTAC-3'. PCR reactions were performed in a volume of $25 \mu \mathrm{L}$ containing $10 \mathrm{mM}$ Tris- $\mathrm{HCl}(\mathrm{pH} \mathrm{8.3)}$, $50 \mathrm{mM} \mathrm{KCl}, 2 \mathrm{mM} \mathrm{MgCl} 2,200 \mathrm{uM}$ dNTP, $1.3 \mathrm{uL}$ of $1 \%$ bovine serum albumin, $50 \mathrm{pmol}$ of each primer, $100 \mathrm{ng}$ of genomic DNA, and 1 U of Taq polymerase (Invitrogen). Amplification was performed in a Thermal Cycler (MJ research, Inc. Watertown, MA, USA) according to Louws et al. [9] and the PCR products $(25 \mu \mathrm{L})$ were submitted to electrophoresis in $2.0 \%$ agarose gels and stained with ethidium bromide.

ITS rDNA: The isolates were also assessed by the internal transcribed spacer of rDNA (PCR-RFLP), using the procedure as initially used [10]. The amplification products were digested using randomly selected eight restriction enzymes (Alu I, Bam H1, Bgl II, Dra 1, Eco R1, Hae III, Hind III, and Hinf 1). The products of digestion were separated through the gel electrophoresis in $2 \%$ agarose. The reaction was analyzed in a total volume of $20 \mu \mathrm{L}$ containing $1.5 \mu \mathrm{L}$ of restriction enzyme. DNA digestion was performed according to the instructions of the supplier. All the amplifications and digestions were repeated at least once to make sure the repeatability of the reactions.

\section{Results and Discussion}

In glasshouse inoculations virulence spectrum showed phenotypic variation among some isolates. Although the resistance of genotypes CNPA BA-2003-2059 and FMT 02102996 as identified in earlier studies is governed by two different genes $[2,4]$, these genotypes showed a susceptible reaction to three isolates $13.2,17.5$ and 58.4 originated from three different Brazilian States (Table 1). With the exception of isolates 22.3 and 42.7, genotype FMT 701 was susceptible to all the 16 isolates of $R$. areola. These results confirm the earlier findings [3].

The ERIC/REP primers revealed polymorphism among the isolates. The number of bands varied from 4 to 15 and their sizes ranged from 150 to $1000 \mathrm{bp}$ (Figures 1 and 2). The dendrograms showed almost a unique profile for both ERIC and REP analysis for most isolates (Figures 3 and 4). 
Table 1. Origin of 16 Ramularia areola isolates of Gossypium hirsutum and their virulence pattern on three cotton genotypes.

\begin{tabular}{clccc}
\hline \multirow{2}{*}{ Isolate of $\boldsymbol{R}$. areola } & Location and State of origin & \multicolumn{2}{c}{ Cotton genotype and its reaction to R. areola isolates* } \\
\cline { 3 - 5 } 12.8 & Moreira Sales, Paraná & FMT 701 & FMT 996 & CNPA BA 2003-2059 \\
\hline 13.2 & Sto. Ant. da Platina, Paraná & $\mathrm{S}$ & $\mathrm{MR}$ & $\mathrm{R}$ \\
17.5 & Riolândia, São Paulo & $\mathrm{S}$ & $\mathrm{S}$ & $\mathrm{S}$ \\
18.4 & Riolândia, São Paulo & $\mathrm{S}$ & $\mathrm{R}$ & $\mathrm{R}$ \\
19.4 & Riolândia, São Paulo & $\mathrm{S}$ & $\mathrm{R}$ & $\mathrm{R}$ \\
22.3 & Unknown, Bahia & $\mathrm{R}$ & $\mathrm{R}$ & $\mathrm{R}$ \\
25.1 & Unknown, Bahia & $\mathrm{S}$ & $\mathrm{R}$ & $\mathrm{R}$ \\
26.1 & Unknown, Bahia & $\mathrm{S}$ & $\mathrm{R}$ & $\mathrm{R}$ \\
40.6 & Novo São Joaquim, Mato Grosso & $\mathrm{S}$ & $\mathrm{R}$ & $\mathrm{R}$ \\
41.4 & Primavera do Leste, Mato Grosso & $\mathrm{S}$ & $\mathrm{R}$ & $\mathrm{R}$ \\
42.7 & Campo Verde, Mato Grosso & $\mathrm{R}$ & $\mathrm{R}$ & $\mathrm{R}$ \\
44.1 & Ipameri, Goiás & $\mathrm{S}$ & $\mathrm{R}$ & $\mathrm{R}$ \\
46.4 & Ipameri, Goiás & $\mathrm{S}$ & $\mathrm{R}$ & $\mathrm{R}$ \\
54.1 & Primavera do Leste, Mato Grosso & $\mathrm{S}$ & $\mathrm{R}$ & $\mathrm{S}$ \\
58.4 & Chapada do Sul, Mato Grosso do Sul & $\mathrm{S}$ & $\mathrm{R}$ & $\mathrm{S}$ \\
63.3 & Mineiros, Goiás & & \\
\hline
\end{tabular}

${ }^{*} \mathrm{R}=$ Resistant. No symptoms of the disease; MR = Moderately Resistant. Small necrotic spots along with some chlorosis capable of sporulating in humid chamber, covering $<1 \%$ leaf area infected (LAI); $\mathrm{S}=$ Susceptible. Typical angular spots, 3 - $4 \mathrm{~mm}$, with or without chlorosis and without sporulation, covering $>1 \%$ LAI 30 days after inoculation.

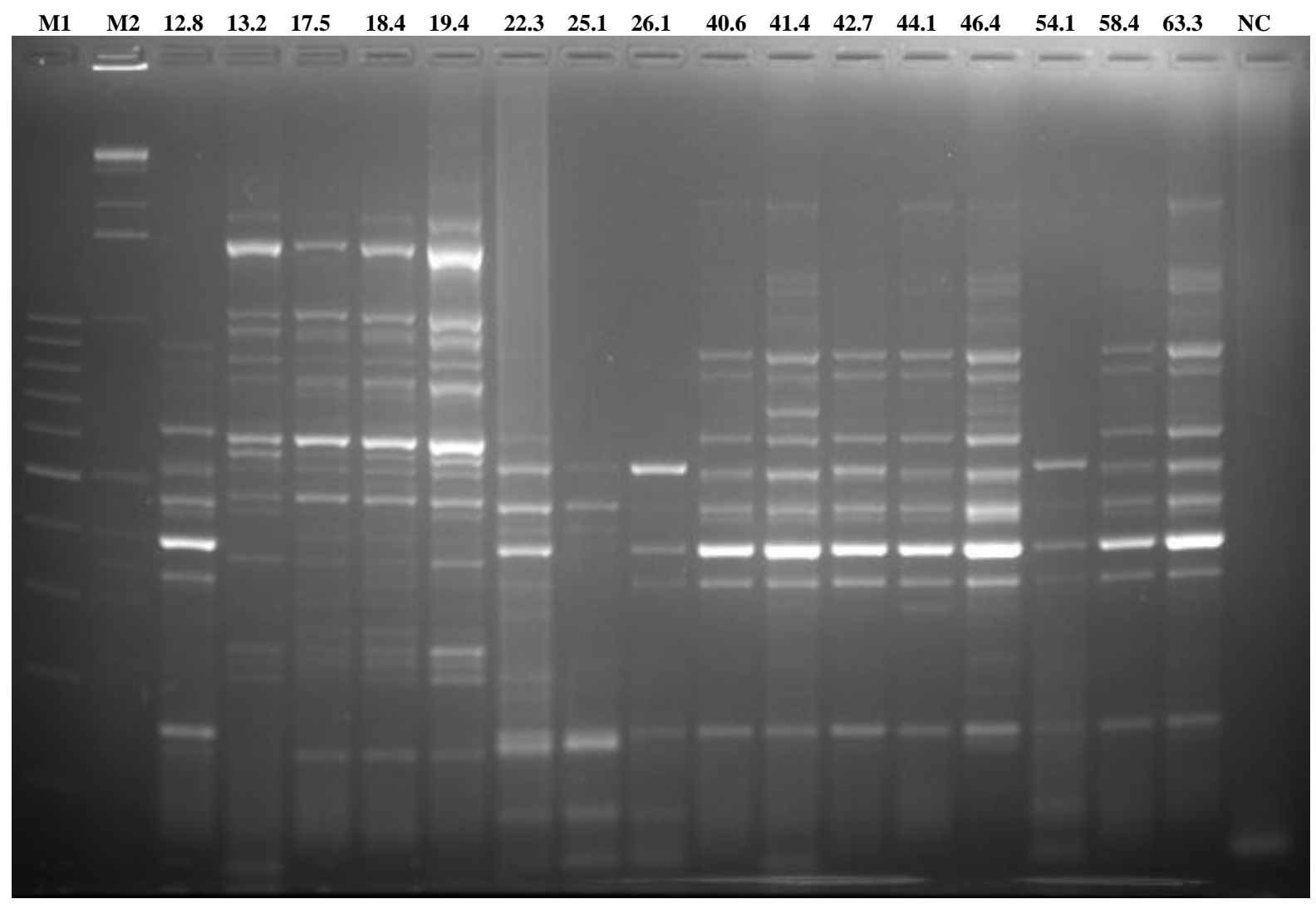

Figure 1. Amplification products of the Ramularia areola isolates using ERIC primers. M1 = molecular maker 100-bp, M2 = 1KbDNA Ladder Thermo Scientific, NC = negative control. 


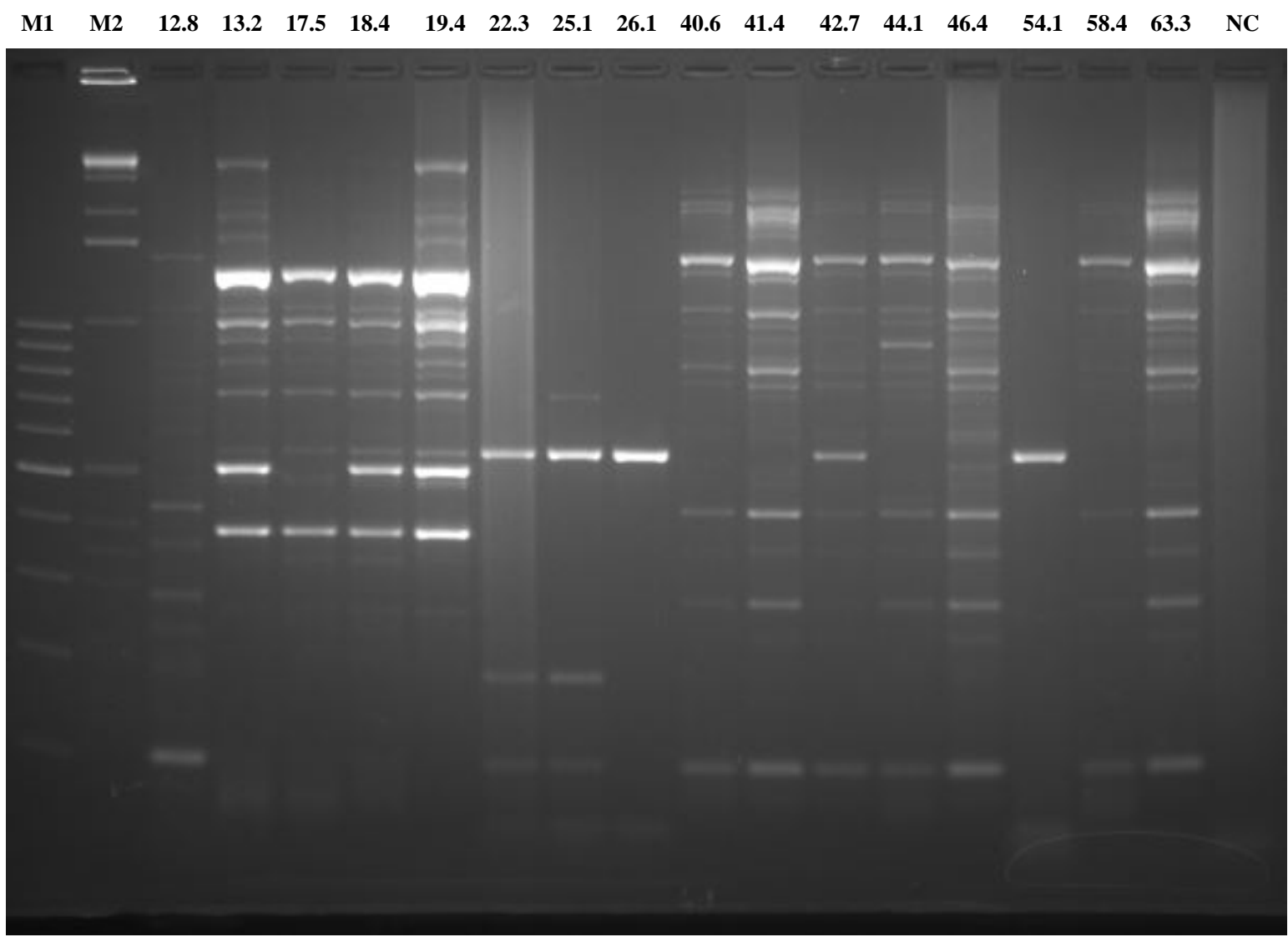

Figure 2. Amplification products of the Ramularia areola isolates using REP primers. M1 = molecular maker 100-bp, M2 = 1KbDNA Ladder Thermo Scientific, NC = negative control.

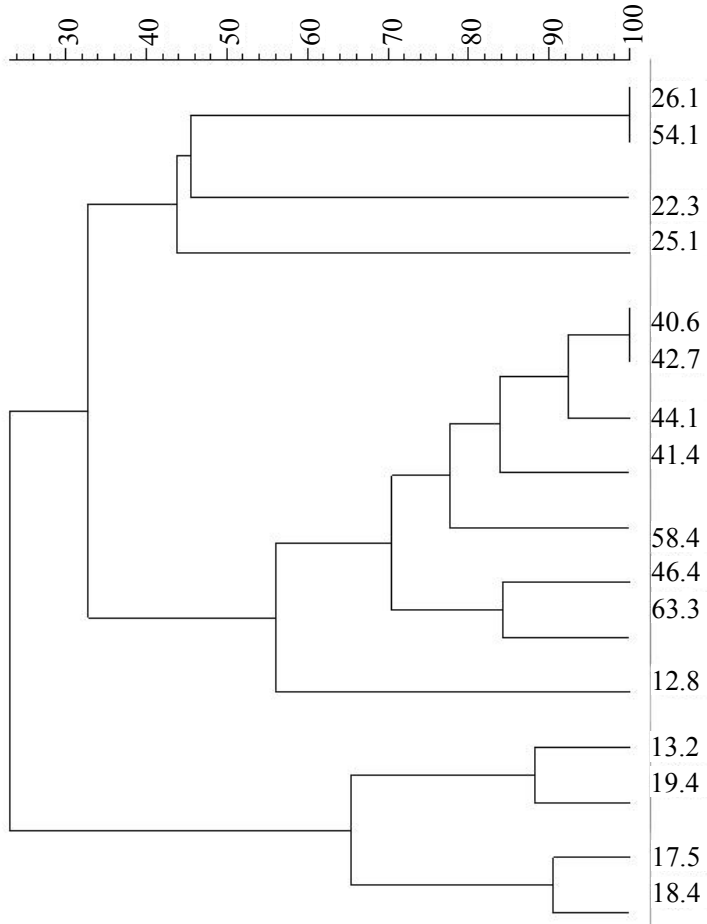

Figure 3. Dendrogram produced by UPGMA cluster analyses based on the primer ERIC for Ramularia areola.

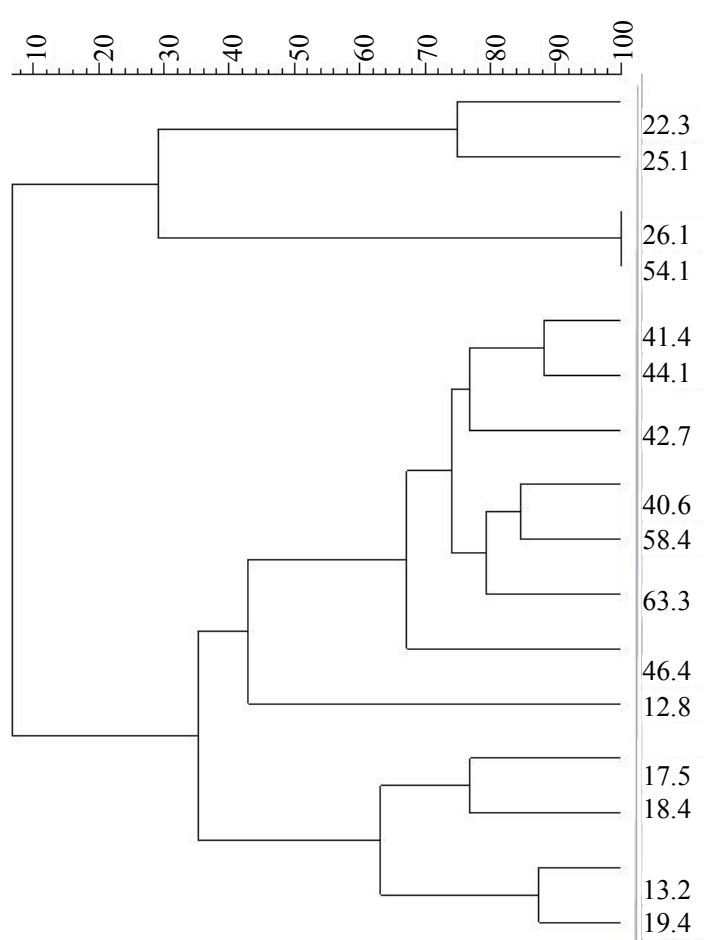

Figure 4. Dendrogram produced by UPGMA cluster analyses based on the primer REP for Ramularia areola. 
The size of the amplified DNA was around $580 \mathrm{bp}$. None of the restriction enzymes was informative. Only the enzyme Hinf 1 was able to cut the DNA of all the pathotypes in three parts but identical banding pattern was observed for all the isolates (Figure 5). Lack of differentiation between the isolates in this analysis perhaps indicates that the minor genes for resistance are not involved.

While some isolates differed among each other considering genotypic and phenotypic reactions, no clear cut evidence was found about the existence of genetic lineages of $R$. areola in Brazil. It is quite understandable that genetically similar isolates may differ in their phenotypic reactions and vice versa. There are some reports in the literature about the use of molecular techniques to distinguish races or pathotypes of fungal and bacterial pathogens $[9,11]$. However, in general, in several other pathosystems no relationship between phenotypic reaction and genetic diversity was observed based on DNA sequences [12].

Identification of existence of variability among the isolates of the pathogen would orient the breeding procedures to create new cultivars with a broader spectrum of resistance against this pathogen. Although we tested only 16 isolates of $R$. areola, the results would serve as a basis for future studies in this area. More detailed information is required to comprehend the virulence frequency and the existance of the genetic lineages if any, using a wider range of cultivars and isolates originating from different cotton growing areas of Brazil. It is possible that other molecular techniques may also show genetic differences among the isolates and assist in identification of distinct genetic lineages of $R$. areola in Brazil. This

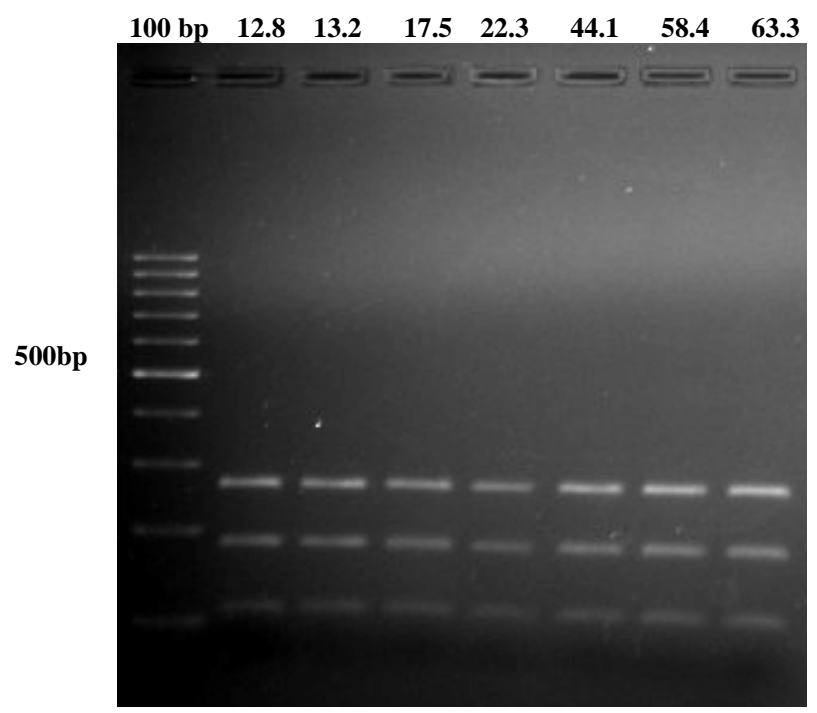

Figure 5. Sample gel showing amplification products of the Ramularia areola isolates using restriction enzyme Hinf $I$. $100 \mathrm{bp}=$ Molecular marker; 12.8 through 63.3 randomly selected isolates of $\boldsymbol{R}$. areola. would assist screening cotton germplasm for resistance against genetic lineages/pathotypes showing perhaps both phenotypic and genotypic variability. Resistance sources identified in this way would remain stable for a longer period of time. Such studies would also assist in establishing differential set of cotton cultivars to identify field strains of $R$. areola in Brazil. This is the first report on the identification genotypic differentiation among the Brazilian isolates of $R$. areola and its relationship with the virulence spectrum.

\section{Conclusion}

Considering the UPGMA cluster analysis formed by ERIC and REP-PCR, it may be concluded that the 16 isolates of $R$. areola fell into three major groups belonging to broadly separated geographical regions. While there existed genotypic and phenotypic variability among the isolates, so far no clear indication was observed as regards the existence of genetic lineages of $R$. areola in Brazil. Results indicate the necessity of using different isolates for screening the germplasm aimed at creating new cultivars with broad spectrum resistance.

\section{Acknowledgements}

Genetic seed material of the cotton genotypes was provided by Camilo de Lelis Morello (Embrapa Algodão Campina Grande, PB, Brazil) and Paulo H. Aguiar (Fundação MT, Rondonópolis, MT, Brazil). The present research was conducted under the financial support of IMA, MT, Brazil. Thanks are also due to Bonnie Vieira and Mariane Vieira for technical assistance.

\section{REFERENCES}

[1] E. Cia, M. G. Fuzzatto, E. J. Chiavegato, F. J. C. Farias and A. E. Araújo, "Desempenho de Cultivares e Linhagens de Algodoeiro Diante da Incidência de Ramularia," Proceedings Congresso Brasileiro de Algodão, Ribeirão Preto, Embrapa Algodão, 1999, pp. 468-470.

[2] T. G. Novaes, W. P. Almeida, I. Schuster and Y. R. Mehta, "Herança de Resistência do Algodoeiro a Ramularia areola," Summa Phytopathologica, Vol. 37, 2011, pp. 150-152. doi:10.1590/S0100-54052011000200012

[3] L. F. Pezenti, J. Barbosa, A. V. Mariane, S. M. Mariana, V. Jessica, W. P. Almeida, R. Galbieri and Y. R. Mehta, "Phenotypic Variability among Isolates of Ramularia areola from Brazilian Cotton," Tropical Plant Pathology, 2013, in Press.

[4] C. Zandoná, T. Novais, M. P. Nunes, W. P. Almeida, I. Shuster and Y. R. Mehta, "Demonstration of Resistance Mechanism and Presence of Different Resistance Genes to Ramularia areola in Two Cotton Genotypes," Tropical Plant Pathology, Vol. 37, No. 3, 2012, pp. 175-178. doi:10.1590/S1982-56762012000300002

[5] J. S. Cauquil and G. L. Sement, "Faux Mildiou du Coton- 
nier (Ramularia areola Atk) Dans le Sud-Ouest de Madagascar," Cotton et Fibers Tropicales, Vol. 28, 1973, pp. 279-286.

[6] Y. Rathaiah, "Reaction of Cotton Species and Cultivars to Four Isolates of Ramularia areola," Phytopathology, Vol. 66, No. 8, 1976, pp. 1007-1009.

doi:10.1094/Phyto-66-1007

[7] U. Raeder and P. Broda, "Rapid Preparation of DNA from Filamentous Fungi," Letters of Applied Microbiology, Vol. 18, 1985, pp. 6503-6508.

[8] F. J. Louws, D. W. Fulbright, C. T. Stephens and F. J. Bruijn, "Differentiation of Genomic Structure by repPCR Fingerprinting to Rapidly Classify Xanthomonas campestris pv. Vasicatoria," Phtopathology, Vol. 85, 1994, pp. 528-536. doi:10.1094/Phyto-85-528

[9] V. Edel, C. Steinberg, I. Avelange and G. L. Alabouvette, "Comparision of Three Molecular Methods for the Characterization of Fusarium oxysporum Strains," Phytopa- thology, Vol. 85, 1995, pp. 579-585. doi:10.1094/Phyto-85-579

[10] Y. R. Mehta, A. Mehta and Y. B. Rosatto, "REP-PCR Binding Patterns and Sequence Analysis of the Internal Transcribed Spacer of rDNA of Stemphylium solani Isolates from Cotton," Current Mycrobiology, Vol. 44, 2002, pp. 323-328. doi:10.1007/s00284-001-0026-4

[11] R. N. Crowhurst, B. T. Hawthorne, E. H. A. Rikkerink and M. D. Templeton, "Differentiation of Fusarium solani f. sp. cucurbitae Races 1 and 2 by Random Amplification of Polymorphic DNA," Current Genetics, Vol. 20, No. 5, 1991, pp. 391-396.

[12] A. S. Prabhu, M. C. Filippi and L. G. Araujo, "Pathotype Diversity of Pyricularia grisea from Improved Upland Rice Cultivars in Experimental Plots," Fitopathologia Brasileira, Vol. 27, No. 5, 2002, pp. 468-473. doi:10.1590/S0100-41582002000500005 